\title{
Design and Structural Analysis of Precast Concrete Wall Panel Using Metal Furring as Vertical Reinforcement
}

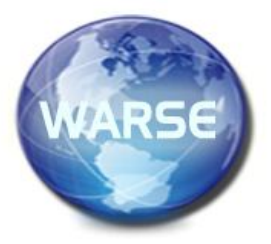

\author{
Jullie Ann I. De La Cruz, MSCE ${ }^{1}$, Nathaniel C. Tarranza, M. Eng ${ }^{2}$ \\ ${ }^{1}$ Xavier University, Cagayan de Oro City, Philippines, jdelacruz@xu.edu.ph \\ ${ }^{1,2}$ Mindanao State University, Iligan Institute of Technology, Philippines, nathanieltarranza@yahoo.com
}

deemed available, regardless of how uncomfortable and unsuitable the living situation may be.

To assure that the people will have a decent home after disasters, cheap and strong materials are needed for the reconstruction of the houses. These materials must be readily installed and must possess the needed durability and strength. Some solutions to these problems are the use of composite materials like bamboos and concrete wall panels [3], [4] and [5]. The materials used for the construction of these houses require carefully analysis to tests their strengths when undergoing heavy stress and mechanical strains. Examples of these tests are shown in several research papers [6], [7], [8], [9], [10] and [11] that demonstrate the mechanical properties of each material. The thickness and volumes of these materials are also important, as well as the manner on how they are constructed [12], [13] and [14]. Precast concrete walls [15] are also proposed by some researchers in building these houses. This research presents the design and analysis of precast concrete wall panel using metal furring as vertical reinforcement for houses!

\section{PROBLEM STATEMENT}

Several designs of wall panels are already available in the market today. Studies and researches to improve these designs have continuously been performed. Most of the wall panels, more commonly known as "sandwich panels," are marketed to target thermal insulation, sound proofing, lightweight material, ease of installation, bending/flexure capacity, and shear capacity. However, there are still no studies that elucidate the complete package of shear, flexure and compressive capacities in one Wall Panel System. The results of the characterization of the strength of the pre-cast concrete wall panel will provide significant data on the factors that affect its structural capacity.

The expected efficiency and stability of the pre-cast concrete material will serve as a standard structural member which would lessen the sizes of the reinforced concrete beams in building constructions since these beams contribute as a load carrying structural member.

The objective of this study is to come up with the design of a pre-cast concrete wall panel with metal furring as vertical reinforcements which involves analysis on concrete design mix, material properties, and strength of the wall panel. This study aims to design a pre-cast concrete wall panel with 
metal furring as vertical reinforcement and then test the wall panel design against shear, compression and flexural actions and compare the results of theoretical computation to its actual strengths. Lastly, cost comparison between the precast concrete wall panel, reinforced with metal furring and the conventional concrete hollow-blocked wall will be conducted. Its application is expected to produce fast, strong, and cheap construction necessary in every disaster risk management's infrastructural need. With this standard, rapid response to housing needs is very much possible without sacrificing the quality and safety of the community.

This study is limited only to the structural analysis of the Wall Panel System's present design as per manufacturer's specifications. The maximum load capacity to be identified is only limited in comparison to the Shear Strength and Compressive Strength of a $250 \mathrm{~mm} \times 250 \mathrm{~mm}$ beam that could carry $200 \mathrm{kN}$ or $167 \mathrm{kN} / \mathrm{m}$ load, having a shear strength of $100 \mathrm{kN}$, and a flexure strength in comparison to the conventional Concrete Hollow Blocks (CHB) with allowable flexural strength of $6.3 \mathrm{kN}$.

\section{METHODOLOGY}

The design and structural analysis of a precast concrete wall panel was conducted by completing the four phases of the study which includes the preliminaries, designing, preparation, fabrication and testing, and economic analysis. Figure 1 shows the four major phases of this study.

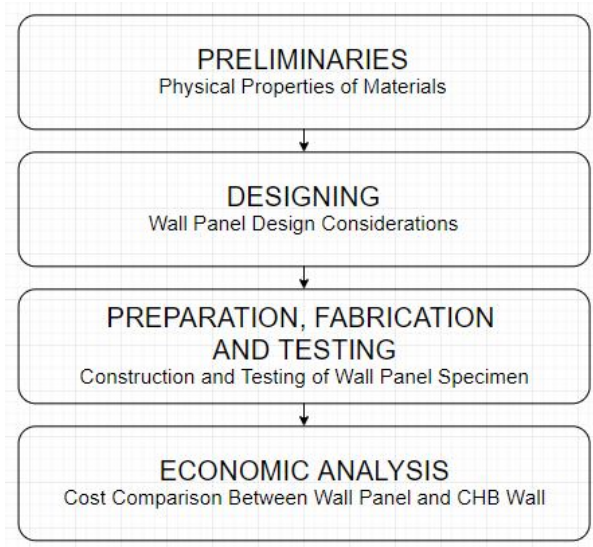

Figure 1: Four Major Phases of the Precast Concrete Wall Design and Structural Analysis

\subsection{Preliminary Tests}

Various tests were conducted to determine the engineering properties and suitability of aggregates, cement, and concrete. In addition, the properties of the metal furring and the deformed bars were also obtained because these are necessary in the calculation of the wall panel's theoretical capacity against flexure, shear, and axial compression. All tests conformed to the ASTM standards and specifications.

For the aggregates, the following tests were conducted such as the Determination of Resistance to Degradation of Small Size Coarse Aggregates by Abrasion and Impact in the Los
Angeles Machine (ASTM C131), Organic Impurities in Fine Aggregates for Concrete (ASTM C40), Clay Lumps and Friable Particles (ATM C142), Bulk Unit Weight (ASTM C39), Specific Gravity and Absorption (ASTM C127 for fine aggregates and ASTM C128 for coarse aggregates), Moisture Content (ASTM C566), and Sieve Analysis (ASTM C136).

For the Portland cement, the following tests were performed including the Determination of \% Fineness (ASTM C786), $\%$ Autoclave Expansion (ASTM C151), Specific Gravity (C188), Vicat Test for Time of Setting (ASTM C191) and Compressive Strength (ASTM C109/ C109M).

For the metal furring, the standard test method for mechanical testing of steel products (more specifically the Tension Test) was based on ASTM A370. These tests are shown in figure 2 below.

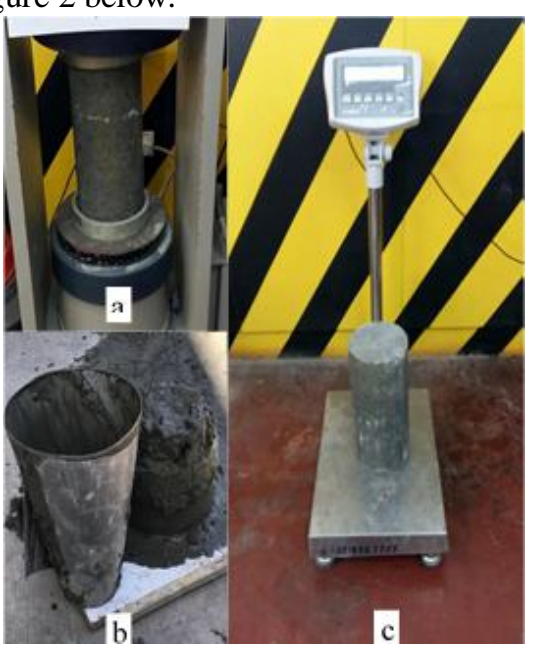

Figure 2: Compression Test; b.) Slump Test; and c.) Unit Weight Test of Concrete

\subsection{Trial Mix Design}

The trial mix design was done after obtaining the engineering properties of the materials. The design of a concrete mixture is the determination of the relative proportions of cement, fine aggregates, coarse aggregate and water. The concrete mixture is designed to give the most economical and practical combination of the materials that will produce the desired workability, strength and durability.

Table 1: Composition and Strength of Concrete for Use in

\begin{tabular}{|c|r|r|c|c|c|c|}
\hline \multirow{2}{\text{Classof}}{$\begin{array}{c}\text { Min. } \\
\text { Concret } \\
\mathbf{e}\end{array}$} & $\begin{array}{c}\text { cement } \\
\text { content/m } \\
\mathbf{3}\end{array}$ & $\begin{array}{c}\text { Max } \\
\text { water } \\
\text { cemen } \\
\text { t ratio }\end{array}$ & $\begin{array}{c}\text { Consistenc } \\
\text { y range in } \\
\text { slump, mm }\end{array}$ & $\begin{array}{c}\text { Designate } \\
\text { d size of } \\
\text { coarse } \\
\text { aggregate } \\
\text { kg }\end{array}$ & $\begin{array}{c}\text { Min } \\
\boldsymbol{f}^{\prime} \\
\text { at 28 } \\
\text { days } \\
\text { bag }\end{array}$ \\
\hline A & 360 & 9.0 & 0.53 & $50-100$ & $1.5 "-\# 4$ & 20.7 \\
\hline B & 320 & 8.5 & 0.58 & $50-100$ & $2.0 "-\# 4$ & 16.5 \\
\hline C & 380 & 9.5 & 0.55 & $50-100$ & $1 / 2 "-\# 4$ & 20.7 \\
\hline P & 440 & 11.0 & 0.49 & 100 max & $3 / 4 "-\# 4$ & 37.7 \\
\hline Seal & 380 & 9.5 & 0.58 & $100-200$ & $1.0 "-\# 4$ & 20.7 \\
\hline
\end{tabular}


Table 2: Approximate Sand and Water Contents for Concrete

\begin{tabular}{|c|c|c|c|c|c|c|}
\hline \multirow{3}{*}{$\begin{array}{c}\text { Maximum } \\
\text { size of } \\
\text { aggregate }\end{array}$} & \multicolumn{3}{|c|}{$\begin{array}{l}\text { Rounded Coarse } \\
\text { Aggregate }\end{array}$} & \multicolumn{3}{|c|}{$\begin{array}{c}\text { Angular Coarse } \\
\text { Aggregate }\end{array}$} \\
\hline & \multirow{2}{*}{$\begin{array}{c}\text { Sand \% of } \\
\text { Total } \\
\text { Aggregate } \\
\text { by } \\
\text { Absolute } \\
\text { Volume } \\
\mathrm{m}^{3}\end{array}$} & \multicolumn{2}{|c|}{$\begin{array}{c}\text { Net Water } \\
\text { Content } \\
\text { per } \mathbf{m}^{3}\end{array}$} & \multirow{2}{*}{$\begin{array}{c}\text { Sand \% of } \\
\text { Total } \\
\text { Aggregate } \\
\text { by } \\
\text { Absolute } \\
\text { Volume } \\
\mathrm{m}^{3} \\
\end{array}$} & \multicolumn{2}{|c|}{$\begin{array}{c}\text { Net } \\
\text { Water } \\
\text { Content } \\
\text { per } \mathbf{m}^{\mathbf{3}}\end{array}$} \\
\hline & & $\mathrm{kg}$ & $\mathrm{L}$ & & $\mathrm{kg}$ & $\mathrm{L}$ \\
\hline 12.5 & 51 & 199 & 199 & 56 & 214 & 214 \\
\hline 19.0 & 46 & 184 & 184 & 51 & 199 & 199 \\
\hline 25.0 & 41 & 178 & 178 & 46 & 192 & 192 \\
\hline 37.5 & 37 & 166 & 166 & 42 & 181 & 181 \\
\hline 50.0 & 34 & 157 & 157 & 39 & 172 & 172 \\
\hline 75.0 & 31 & 148 & 148 & 36 & 163 & 163 \\
\hline 150.0 & 26 & 131 & 131 & 31 & 146 & 146 \\
\hline
\end{tabular}

Table 3: Table of Adjustments for Other Conditions

\begin{tabular}{|l|c|c|}
\hline \multicolumn{1}{|c|}{$\begin{array}{c}\text { Changes in condition } \\
\text { stipulated in Table 2 }\end{array}$} & $\begin{array}{c}\text { Effect in Values in } \\
\text { Table 3.2 }\end{array}$ \\
\cline { 2 - 3 } & $\begin{array}{c}\text { Percent } \\
\text { Sand }\end{array}$ & $\begin{array}{c}\text { Net } \\
\text { Water } \\
\text { Content }\end{array}$ \\
\hline $\begin{array}{l}\text { Each 0.05 increase / decrease on } \\
\text { water cement ratio }\end{array}$ & \pm 1 & 0 \\
\hline $\begin{array}{l}\text { Each 0.1 increase / decrease in } \\
\text { fineness modulus of sand }\end{array}$ & $\pm 1 / 2$ & 0 \\
\hline $\begin{array}{c}\text { Each 25 mm increase / decrease in } \\
\text { slump }\end{array}$ & 0 & $\pm 3 \%$ \\
\hline Manufactured sand & +3 & $+8.9 \mathrm{~kg}$ \\
\hline $\begin{array}{c}\text { For less workable concrete as } \\
\text { pavement }\end{array}$ & -3 & $-4.7 \mathrm{~kg}$ \\
\hline
\end{tabular}

Tables 1 to 3 show the contents and strengths of the concrete used.

\subsection{Design Considerations and Requirements}

The design of wall panel was based on the NSCP 2015 requirements was only focused on three major tests for non-prestressed pre-cast wall panel namely compression, flexural, and shear. The details of the wall panel design reinforced with metal furring along the longitudinal axis for flexural failure and $9 \mathrm{~mm} \emptyset$ bar along the transverse axis for shear action is shown in Table 4 and Figure 3.

Table 4: Details of the Wall Panel Design

\begin{tabular}{|l|l|}
\hline length of specimen & \multicolumn{1}{|c|}{$2.40 \mathrm{~m}$} \\
\hline width of specimen & $1.20 \mathrm{~m}$ \\
\hline thickness of specimen & $90 \mathrm{~mm}$ \\
\hline spacing of metal furring & $230 \mathrm{~mm}$ \\
\hline $\begin{array}{l}\text { number of metal furring required }(19 \mathrm{~mm} x \\
50 \mathrm{~mm} x 0.40 \mathrm{~mm})\end{array}$ & $6 \mathrm{pcs}$. \\
\hline spacing of $9 \mathrm{~mm} \emptyset$ bar & $290 \mathrm{~mm}$ \\
\hline number of $9 \mathrm{~mm} \emptyset$ required & $9 \mathrm{pcs}$. \\
\hline
\end{tabular}

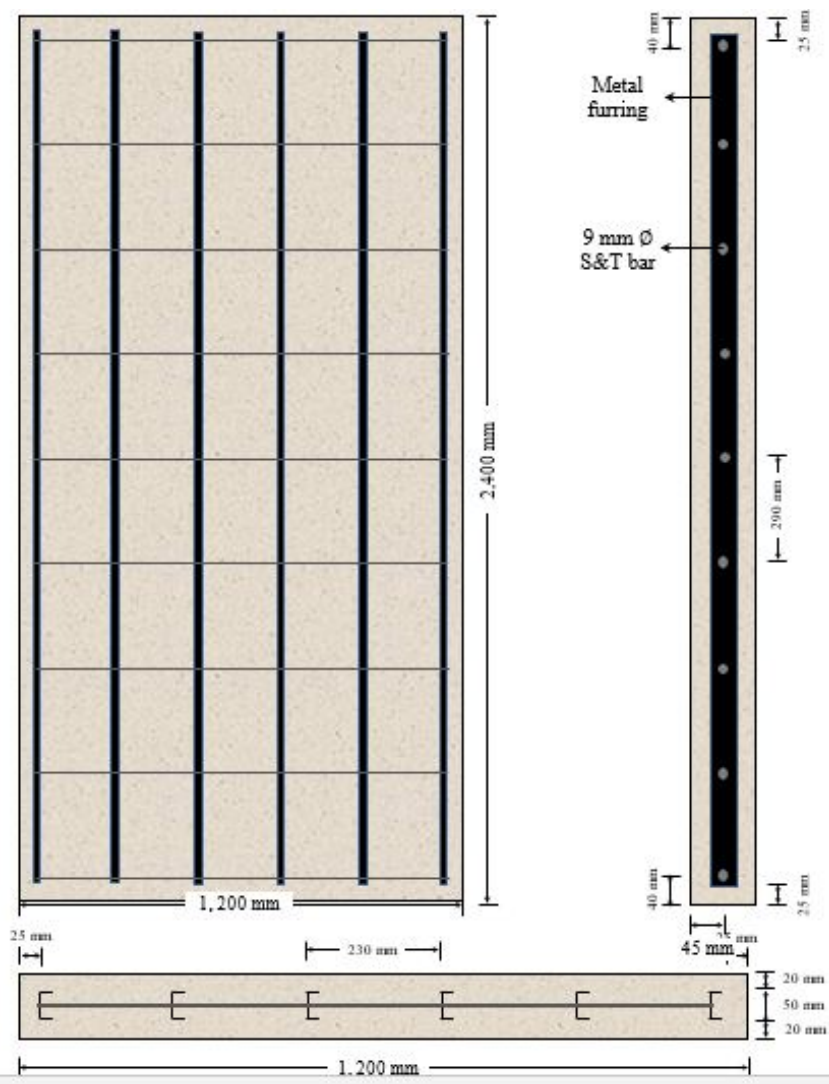

Figure 3: 2D Visualization of Wall Panel Design

\subsection{Fabrication, Demolding and Curing of Specimens}

\subsubsection{Fabrication of Formworks}

A total of 15 wall panel specimens were prepared for the 3 strength tests (axial, flexure, and shear), each with 5 replicates. Various materials and tools were used including $1 / 2$ " ordinary plywood, 4" common wire nails, 1" finishing nails, 2" x 2" x 10' Coco lumber, used engine oil, wood saw, hammer, and measuring tape.

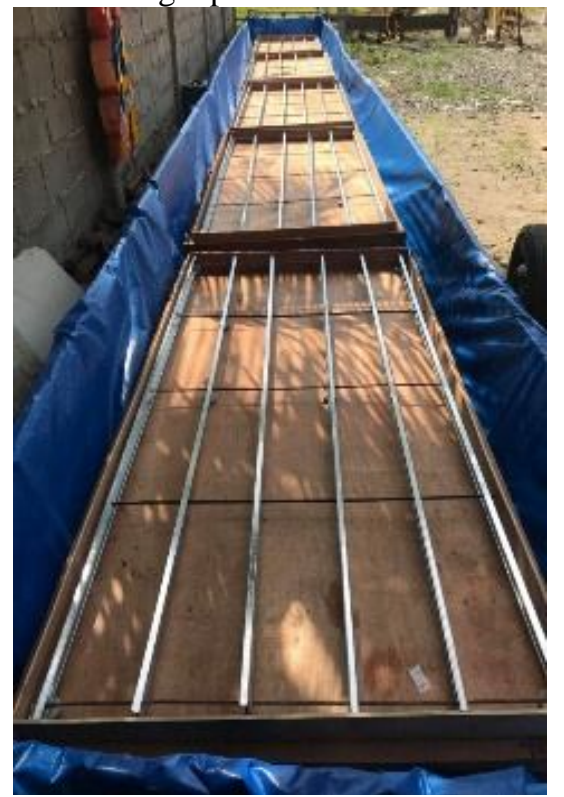

Figure 4: Formworks for Wall Panel Specimens 


\subsubsection{Concrete Mixing and Casting of Wall Panel Specimen}

The mixing process consists of blending all the ingredients of fresh concrete including cement, sand, gravel and water into a uniform mass. Various materials were used including formworks, trowel, tamping rod and pail. In this process the portable concrete mixer was used. The necessary quantity of coarse aggregates and half the required amount the water were placed into the mixer. The mixer was then turned on, adding all the remaining ingredients including sand, cement, and the rest of the water. The mixing continued until the materials were thoroughly mixed.

\subsubsection{Curing of Wall Panel Samples}

Curing is the process of keeping the moisture content and temperature in concrete while attaining the required strength within a specified length of time. Appropriate curing is essential because it has a strong impact on the durability, strength, volume stability, abrasion resistance and other properties of concrete.

\subsubsection{Strength Tests of Wall Panel}

The static load test used a hydraulic jack hammer in determining the capacity of wall specimen against compression, flexure, and shear action

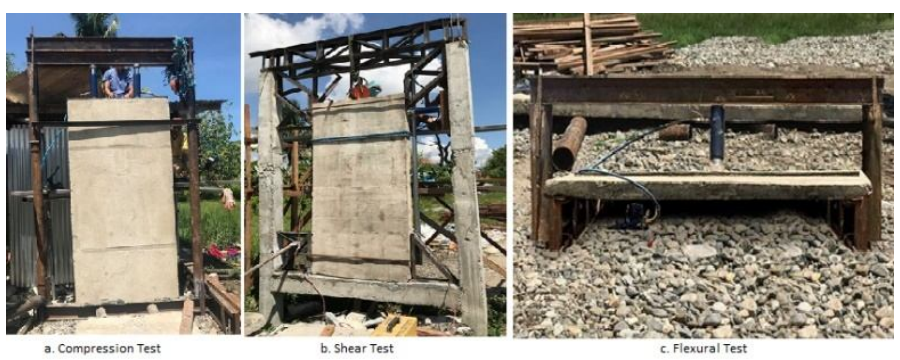

Figure 5: strength Tests for the specimen

\subsection{Economic Analysis of Wall Panel Design}

This section presents the evaluation of the viability of the wall panel design against the existing load-bearing CHB wall design in terms of cost - to - strength ratio. The concept of the analysis of cost per strength can be explained as follows. Lower cost and lower strength simply mean that the design has a poor quality while higher cost and higher strength indicate that the design has good quality. However, higher cost and lower strength signify that the quality is being sacrificed. Fortunately, lower cost but higher strength will produce the best design in terms of safety and economy. Therefore, the design with lowest cost to strength ratio will be selected.

For the cost estimate of wall designs, only the material cost is included to make the study more specific. The labor cost and the cost of formworks are neglected in the calculation because of their great variability in relation to the number of manpower needed, the length of time to finish the fabrication, availability and type of formworks needed, and other related factors.

For the strength of wall designs, the axial load capacity was considered. For the precast wall panel, the strength was obtained from actual test. For the existing load - bearing CHB wall, the axial load capacity was based on the minimum compressive strength of 4.82 $\mathrm{MPa}$ (NSCP, 2015) and bearing area of approximately $32500 \mathrm{~mm}^{2}$. Non-load bearing masonry units as indicated in ASTM C129 shall have a minimum compressive strength of $3.45 \mathrm{MPa}$. Whereas, this wall panel weighs an average of $60.02 \mathrm{kN}$.

\section{RESULTS AND DISCUSSIONS}

This chapter presents the various test results of the study including the material properties, strength tests, statistical tests and economic analysis of the wall panel design.

Table 5: Test Results for the Suitability of Materials

\begin{tabular}{|c|c|c|c|}
\hline Materials & $\begin{array}{l}\text { Type of Test } \\
\text { Conducted }\end{array}$ & Results & $\begin{array}{c}\text { Specification } \\
\text { Limits }\end{array}$ \\
\hline \multirow[b]{2}{*}{$\begin{array}{c}\text { Coarse } \\
\text { Aggregates }\end{array}$} & $\begin{array}{l}\text { Test for Clay } \\
\text { Lumps and } \\
\text { Friable } \\
\text { Particles in } \\
\text { Aggregates } \\
\text { (ASTM C142) }\end{array}$ & $0.03 \%$ & $0.25 \% \max$ \\
\hline & $\begin{array}{l}\text { Resistance to } \\
\text { Degradation } \\
\text { of Small - } \\
\text { Size Coarse } \\
\text { Aggregates by } \\
\text { Abrasion and } \\
\text { Impact in the } \\
\text { Los Angeles } \\
\text { Machine } \\
\text { (ASTM C131) }\end{array}$ & $22 \%$ & $40 \% \max$ \\
\hline \multirow[b]{2}{*}{$\begin{array}{c}\text { Fine } \\
\text { Aggregates }\end{array}$} & $\begin{array}{l}\text { Test for Clay } \\
\text { Lumps and } \\
\text { Friable } \\
\text { Particles in } \\
\text { Aggregates } \\
\text { (ASTM C142) }\end{array}$ & $0.23 \%$ & $1.00 \% \max$ \\
\hline & $\begin{array}{l}\text { Test for } \\
\text { Organic } \\
\text { Impurities in } \\
\text { Fine } \\
\text { Aggregates for } \\
\text { Concrete } \\
\text { (ASTM C40) }\end{array}$ & Lighter & N/A \\
\hline
\end{tabular}


Table 6: Specific Gravity, Absorption, and Bulk Density of Aggregates

\begin{tabular}{|l|c|c|}
\hline \multicolumn{1}{|c|}{ Properties } & $\begin{array}{c}\text { Coarse } \\
\text { Aggregate }\end{array}$ & $\begin{array}{c}\text { Fine } \\
\text { Aggregate }\end{array}$ \\
\hline Apparent specific gravity & 2.677 & 2.818 \\
\hline $\begin{array}{l}\text { Specific gravity oven - } \\
\text { dried }\end{array}$ & 2.545 & 2.642 \\
\hline Specific gravity S.S.D & 2.595 & 2.704 \\
\hline Water absorption & 2.022 & 2.370 \\
\hline Bulk Density (Loose) & $1,458 \mathrm{~kg} / \mathrm{m}^{3}$ & $1,668 \mathrm{~kg} / \mathrm{m}^{3}$ \\
\hline Bulk Density (Compacted) & $1,575 \mathrm{~kg} / \mathrm{m}^{3}$ & $1,777 \mathrm{~kg} / \mathrm{m}^{3}$ \\
\hline
\end{tabular}

Table 7: Yield Strength of Metal Furring

\begin{tabular}{|c|c|}
\hline Sample Designation & Yield Strength, $\mathbf{f}_{\mathbf{y}}$ (MPa) \\
\hline $\mathrm{T}-1$ & 235.98 \\
\hline $\mathrm{T}-2$ & 260.78 \\
\hline $\mathrm{T}-3$ & 246.96 \\
\hline Average & $\mathbf{2 4 7 . 9 1}$ \\
\hline
\end{tabular}

Table 8: Compressive strength of concrete

\begin{tabular}{|c|c|}
\hline Sample Designation & $\begin{array}{c}\text { Compressive Strength, } \mathbf{f}_{\mathbf{c}}^{\prime} \\
\text { (MPa) }\end{array}$ \\
\hline $\mathrm{C}-1$ & 24.2 \\
\hline $\mathrm{C}-2$ & 24.1 \\
\hline $\mathrm{C}-3$ & 24.0 \\
\hline Average & $\mathbf{2 4 . 1}$ \\
\hline
\end{tabular}

Table 9: Slump Test Result

\begin{tabular}{|c|c|}
\hline Sample Designation & Slump Value (mm) \\
\hline $\mathrm{S}-1$ & 88.9 \\
\hline $\mathrm{S}-2$ & 76.2 \\
\hline $\mathrm{S}-3$ & 88.9 \\
\hline Average & $\mathbf{8 4 . 7}$ \\
\hline
\end{tabular}

Table 10: Unit Weight of Concrete

\begin{tabular}{|c|c|c|c|}
\hline $\begin{array}{c}\text { Sample } \\
\text { Designation }\end{array}$ & $\begin{array}{c}\text { Weight } \\
(\mathbf{k g})\end{array}$ & $\begin{array}{c}\text { Volume } \\
\left(\mathbf{m}^{\mathbf{3}}\right)\end{array}$ & $\begin{array}{c}\text { Unit weight } \\
\left(\mathbf{k N} / \mathbf{m}^{\mathbf{3}}\right)\end{array}$ \\
\hline $\mathrm{W}-1$ & 12.50 & 0.005301 & 23.13 \\
\hline $\mathrm{W}-2$ & 12.46 & 0.005301 & 23.06 \\
\hline $\mathrm{W}-3$ & 12.58 & 0.005301 & 23.28 \\
\hline \multicolumn{4}{|c|}{ Average } \\
\hline
\end{tabular}

Table 11 below shows the summary of the amount of various materials needed in the fabrication of wall panel including cement, sand, gravel, and water. The mix proportion was obtained by dividing the last column with the amount of cement needed resulting to $1: 2.50: 2.72: 0.486$.
Table 11: Trial Batch of the Concrete Ingredients

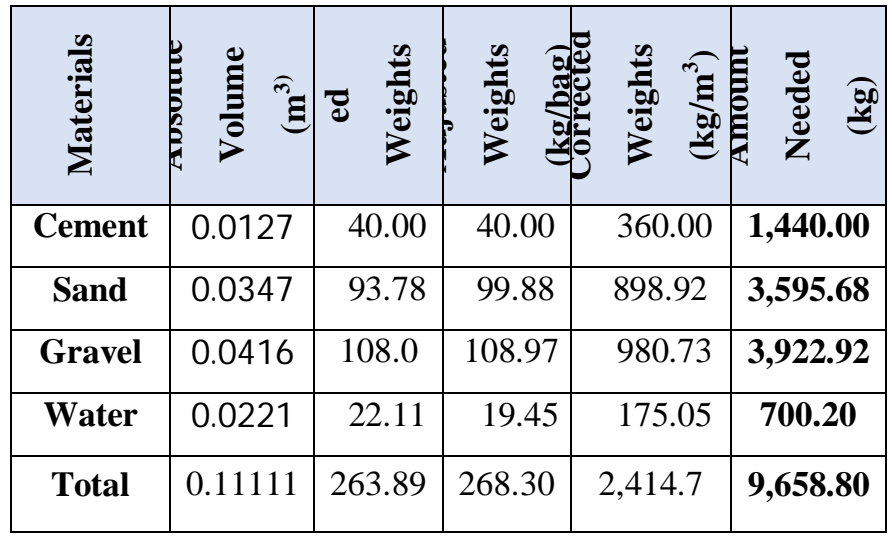

Table 12 shows the design loads of the wall panel based on flexure, shear, and compression (see Appendix D for detailed calculation). The safest load has the least value which is governed by the flexural action.

Table 12: Design Load of Wall Panel

\begin{tabular}{|c|c|c|c|}
\hline $\begin{array}{c}\text { Type of Strength } \\
\text { Test }\end{array}$ & Flexure & Shear & Compression \\
\hline Design Load & $4.90 \mathrm{kNm}$ & $\begin{array}{c}46.76 \\
\mathrm{kN}\end{array}$ & $437.42 \mathrm{kN}$ \\
\hline
\end{tabular}

\subsection{Actual Load Capacity of the Wall Panel}

The following figures show the actual strength tests for flexure (Figure 6), shear (Figure 7), and axial compression (Figure 8), respectively. The variation of the actual load capacity of each test is clearly presented. On the average, the wall panel design has a flexural capacity of $5.00 \mathrm{kNm}$, shear capacity of $54.6 \mathrm{kN}$, and axial load capacity of $358 \mathrm{kN}$. Among the three tests, the flexural load is governed. Thus, the safe load is $5.84 \mathrm{kN}$.

The average actual axial stress of $3.78 \mathrm{MPa}$, revealed the significance of the wall panel's capacity to be greater than the standard non-loadbearing masonry unit indicated in ASTM C129 which is only 3.45 MPa.

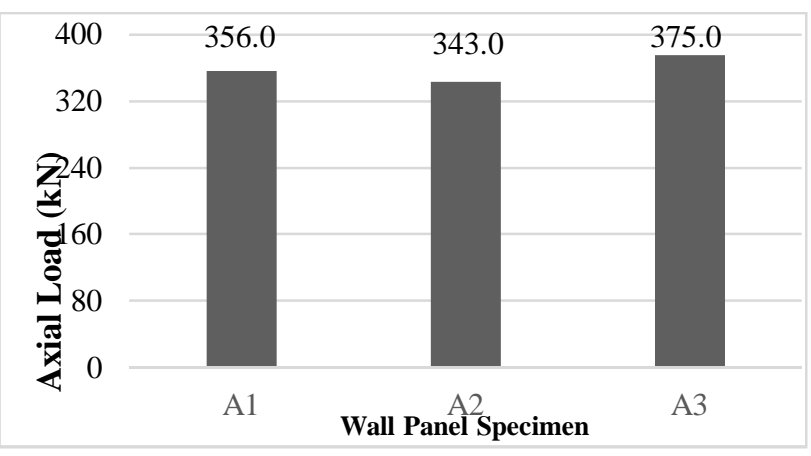

Figure 6: Capacity of Wall Panel Specimen against Axial Load 


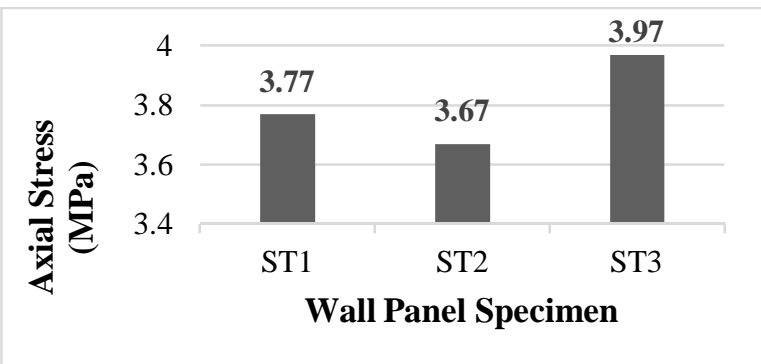

Figure 7: Capacity of Wall Panel Specimen against Axial Stress

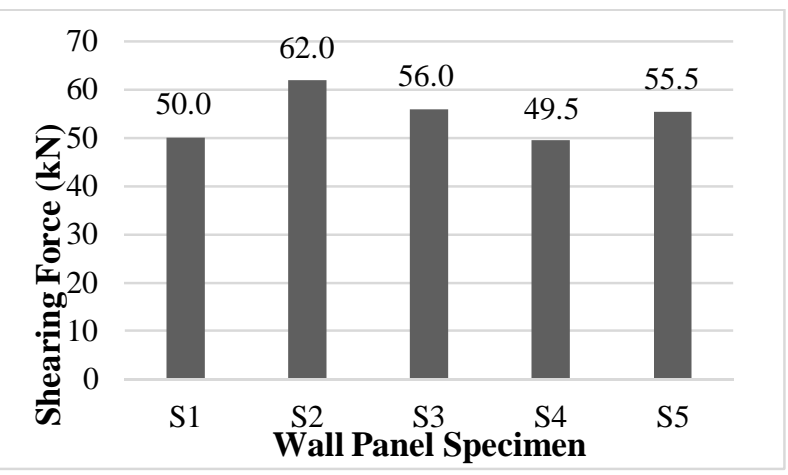

Figure 8: Capacity of Wall Panel Specimen against Shear Load

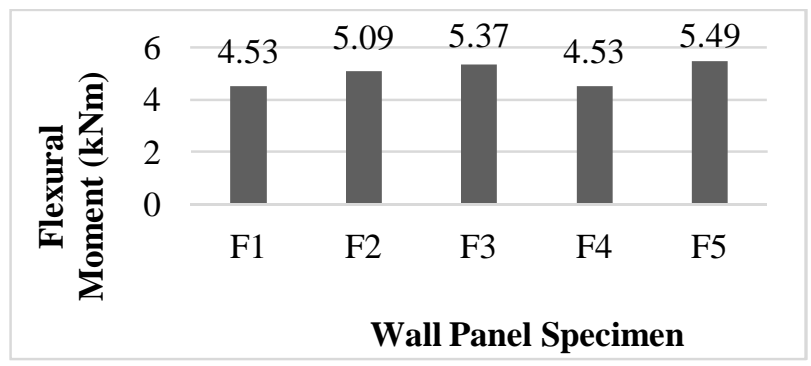

Figure 9: Capacity of Wall Panel Specimen against Flexural Load

\section{CONCLUSION}

It is possible to create a wall panel design with metal furring as main reinforcement. Being stronger and lesser in weight compared to the construction of traditional wall made of non-load bearing $\mathrm{CHB}$ and cement mortar, the wall design is an innovative and viable product for construction that can offer fast and more efficient installation.

Through a series of experimental tests, the structural capacities of the precast wall panel with metal furring reinforcements were defined. It was demonstrated that the response of the wall panel from the actual test against the theoretical values stated in NSCP 2015 is achievable for flexure. However, shear and axial forces shows significant difference. Shear force value is higher while axial force value remained lower than the theoretical results. Performance evidence on this study indicates that the formula suggested by NSCP 2015 is not a suitable model in predicting the shear and axial force values for wall panels.

The axial strength of the wall panel indicates substantial structural performance that could relevantly resist more than three times its own weight when piled up as a vertical structural member.

The cost-to-strength ratio of the wall design was also lower compared to the existing CHB Wall. For this reason, the design can be considered as more economical.

\section{REFERENCES}

[1] Philippine NEDA. (2014). "Economic Impact of Disasters." Manila: National Economic Development Authority.

[2] Tomas U. Ganiron, T. U., Almarwae, M., "Prefabricated Technology in a Modular House", International Journal of Advanced Science and Technology, 73, 51-74. (2014). https://doi.org/10.14257/ijast.2014.73.04

[3] Suhaily S. and Khalil, A. "Bamboo-Based Biocomposites Material, Design and Applications" Bamboo Based Bio-composites Material, Design and Applications http://dx.doi.org/10.5772/56057

[4] Zhou, A, Wong, K., Lau, D. (2014). "Thermal insulating concrete wall panel design for sustainable built environment." The Scientific World Journal Volume 2014, Article ID 279592, 12 pages https://doi.org/10.1155/2014/279592

[5] Girhammar, U. A. "A simplified analysis method for composite beams with interlayer slip." International Journal of Mechanical Sciences, 51(7), 515-530. (2009). https://doi.org/10.1016/j.ijmecsci.2009.05.003

[6] Girhammar, U. A. "Composite beam-columns with interlayer slip-Approximate analysis.", International Journal of Mechanical Sciences, 50(12), 1636-1649. (2008). https://doi.org/10.1016/j.ijmecsci.2008.09.003

[7] Kermani, A., Hairstans, R. "Racking Performance of Structural Insulated Panels.”, Journal of Structural Engineering, 132, 1806-1812. (2006). https://doi.org/10.1061/(ASCE)0733-445(2006)132:11(1806)

[8] Manalo, A. C., Aravinthan, T., \& Karunasena, W., "Flexural behaviour of glue-laminated fibre composite sandwich beams." Composite Structures, 92(11), 2703-2711. (2010). https://doi.org/10.1016/j.compstruct.2010.03.006

[9] Bulay-og, L.L.D., Gustilo, R.C., "Manufacture of sound absorbing material from recycled rice straws for room acoustics improvements", International Journal of Engineering and Technology (UAE), 2018

[10] Luige Vladareanu, Mihaiela Iliescu, Victor Vladareanu, Alexandru Gal, Octavian Melinte, Florentin Smarandache and Adrian Margean, "Improvement of the Material's Mechanical Characteristics using Intelligent Real Time Control Interfaces in HFC Hardening Process", International Journal of Advanced Trends in Computer Science and Engineering, Volume 8 No. 1.1 (2019) S I

[11]Dan Iudean, Alexandru Cretu, Radu Munteanu jr. Rozica Moga, Nicoleta Stroia, Daniel Moga and Luige Vladareanu, "Reliability Approach of a Compressor System using Reliability Block Diagrams", 
International Journal of Advanced Trends in Computer Science and Engineering, Volume 8 No. 1.1 (2019) S I

[12] Olivero et. Al., "Effect of Preform Thickness and Volume fraction on Injection Pressure and Mechanical Properties of Resin Transfer Molded Composites”, Journal of Composite Materials, Vol. 38 No. $11 / 2004$

https://doi.org/10.1177/0021998304040562

[13] Mohammed A. M., Nasim U., "Global buckling of composite structural insulated wall panels," Materials \& Design, 32(2), 766-772. (2011)

https://doi.org/10.1016/j.matdes.2010.07.026

[14] Roberts, J. C., Boyle, M.P., Wienhold, P. D., Ward, E. E. and White, G. J., "Strains and deflections of GFRP sandwich panels due to uniform out-of-plane pressure." Marine Technology and SNAME News, 39(4), 223. (2002).

[15] Yang Jialin; Weichen Xue ; Qin Heng ; Liu Guoquan, "State-of-the-art of precast concrete shear walls", 2011 International Conference on Electric Technology and Civil Engineering (ICETCE), Year: 2011

https://doi.org/10.1109/ICETCE.2011.5776420 